\title{
The Effect of Non-Pharmacological Therapy used in Indonesian Elderly with Hypertension: A Literature Review
}

\author{
Nia Damiati ${ }^{*}$, Rizkiyah Ayu Wulandari ${ }^{2}$ \\ \{nia_damiati@uinjkt.ac.id ${ }^{1}$; rizkiyahayuw1@gmail.com² $\left.{ }^{2}\right\}$ \\ *corresponding author
}

\begin{abstract}
Nursing Study Program, Faculty of Health Sciences, UIN Syarif Hidayatullah Jakarta, Pisangan Ciputat, 15412, Indonesia ${ }^{1,2}$
\end{abstract}

\begin{abstract}
Hypertension is the major risk factor for death as $23.7 \%$ out of around 1.7 million deaths in Indonesia were caused by hypertension. The combination of pharmacological and non-pharmacological management can increase the effectiveness of therapy. This study aimed to collect non-pharmacological therapies in Indonesia that can be used as additional therapy to reduce systolic and diastolic blood pressure in hypertensive elderly. The inclusion criteria used were full text journals indexed by SINTA, ISSN or DOI with the topic of non-pharmacological therapy, samples of pre-elderly hypertension, effective therapy to reduce systolic and diastolic blood pressure with a quasi-experimental design, journals using Indonesian and English with a span of time 2015- 2020. Nonpharmacological therapy used in Indonesian elderly and were effective include dietary regulation, increased physical activity, and relaxation therapy. Future researchers can continue their research with more journals and higher evidence.
\end{abstract}

Keywords: Elderly, Hypertension, Non-Pharmacological Therapy

\section{Introduction}

Currently the world is experiencing the phenomenon of population aging, along with an increase in the number of elderly people over seven percent. It is proven that in 2019 , one in 11 people is elderly and it is estimated that in 2050 it will increase to one in six people who are over 65 years of age [1]. Based on the Central Statistics Agency (BPS), the percentage of the number of elderly people in Indonesia in 2015 reached $8.1 \%$ and in 2019 it increased to $9.7 \%$ of the total population of 25.9 million[2].

The increasing number of diseases in the elderly is caused by physical changes and physiological decline, including those that occur in the cardiovascular, respiratory, musculoskeletal, integumentary, sensory, gastrointestinal, and genitourinary systems [3]. Elderly often experience health problems, such as diabetes mellitus at $4.8 \%$, stroke by $46.1 \%$, arthritis by $51.9 \%$, and hypertension with $57.6 \%$ the highest [4].

Hypertension is a world health problem. The prevalence of hypertension continues to increase, as evidenced by the year 2011-2015 hypertension sufferers in the world amounted to 1 billion and now 1.13 billion. By 2025 it is estimated that there will be 1.5 billion people with hypertension [5]. Increased blood pressure can increase the risk of damage to the heart and blood vessels, as well as large organs such as the brain and kidneys [3]. If this is not handled properly it will result in death. It is proven that deaths due to hypertension constitute $23.7 \%$ of 1.7 billion deaths in Indonesia [6]. 
This requires comprehensive management. Among them are pharmacological therapy and non-pharmacological therapy. The combination of pharmacological and nonpharmacological management is more effective in lowering blood pressure than pharmacological therapy alone. This is in line with a study conducted by 108 respondents, of which $60 \%$ used pharmacological and non-pharmacological combination therapy and $15-40 \%$ only used pharmacological therapy [7].

Research on non-pharmacological therapy in hypertensive patients has been widely conducted in Indonesia, including dietary potassium therapy such as consuming watermelon [8]. Then physical activity therapy such as elderly exercise [9]. There are also therapies for relaxation, such as slow deep breathing [11], progressive muscle relaxation [12], hypnotherapy [13], cupping [15], and mural [16].

However, not all published research results can be used effectively as adjunct therapy to lower systolic and diastolic blood pressure in elderly with hypertension. Given the importance of non-pharmacological therapy as an adjunct therapy, which can increase the effectiveness of treatment. This is in line with Nurhayati's research (2017), there is a decrease in blood pressure that is more effective when given pharmacological and non-pharmacological therapy, namely in the intervention group compared to the control group which is only given drugs or pharmacological therapy. [17]. Therefore, researchers are interested in conducting a literature review (collecting, identifying, and evaluating) the effect of several effective nonpharmacological therapies on reducing systolic and diastolic blood pressure in hypertensive elderly from various published literature.

\section{Method}

A comprehensive search using the Google Scholar electronic search tool, Science Direct, Cambridge, and Pubmed identified 13 literature for review. Keywords used to be entered into the search engine "Terapi Nonfarmakologis AND Penurunan Tekanan Darah AND Hipertensi OR Tekanan Darah Tinggi pada Lansia" as for the others "Non Pharmacological Therapy AND High Blood Pressure OR Hypertension Elderly Patient".

Inclusion criteria journal indexed SINTA, ISSN or DOI with the topic of nonpharmacological therapy. The sample used is pre-elderly with hypertension. Effective therapy lowers systolic and diastolic blood pressure. The journal uses a quasi-experimental design using Indonesian and English with a time span of 2015-2020. Exclusion criteria journals are not full text, the study does not have a control group, and the interventions are not realistic or harmful. 


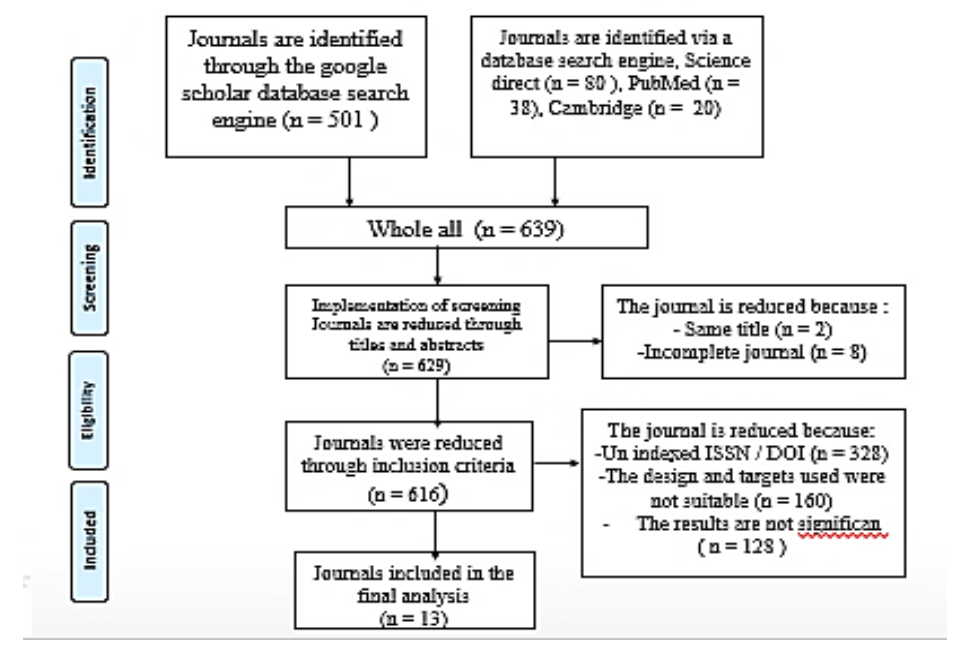

Fig. 1. Summary of literature search and number of articles

Journals were analyzed and evaluated using a transparent evaluation report with a nonrandomized design statement (TREND), with a total of 45 points [19].

\section{Result}

The results showed that there were 13 non-pharmacological studies that proved effective as additional pharmacological therapies to reduce systolic and diastolic blood pressure. The highest decrease in systolic blood pressure was $23.33 \mathrm{mmHg}$ in Elderly Gymnastics. And the highest decrease in diastolic blood pressure was 14.67 watermelon juice, here is the table:

Table 1. The effect of non-pharmacological therapy on blood-pressure in elderly with Hypertension

\begin{tabular}{|c|c|c|c|c|c|}
\hline $\begin{array}{c}\text { NO } \\
.\end{array}$ & $\begin{array}{l}\text { Author } \\
\text { \& year }\end{array}$ & $\begin{array}{l}\text { Type of non- } \\
\text { pharmacologi } \\
\text { cal }\end{array}$ & $\begin{array}{l}\text { Characteri } \\
\text { stic of } \\
\text { samples }\end{array}$ & Measurement & Outcome \\
\hline 1. & $\begin{array}{l}\text { Rina Puspita } \\
\text { Sari, Eti } \\
\text { Nurhayati Kamil, } \\
2017\end{array}$ & $\begin{array}{l}\text { Elderly } \\
\text { Gymnastics }\end{array}$ & $\begin{array}{l}\text { Samples } \\
72 \text { elderly }\end{array}$ & $\begin{array}{l}\text { Sphygmomano } \\
\text { meter and } \\
\text { stethoscope }\end{array}$ & $\begin{array}{l}\text { Therapy is carried out } \\
3-5 \text { times a week with } \\
\text { a duration of } 20-60 \\
\text { minutes of exercise } \\
\text { there was a decrease in } \\
\text { blood pressure of } \\
\text { around } 23.33 \text { and } \\
10.22 \mathrm{mmHg} \text {. }\end{array}$ \\
\hline 2. & $\begin{array}{l}\text { Rebbi Permata } \\
\text { Sari, Ledia } \\
\text { Restipa, Marsia } \\
\text { Yonira Putri, } \\
2017\end{array}$ & $\begin{array}{l}\text { Watermelon } \\
\text { juice }\end{array}$ & $\begin{array}{l}\text { Samples is } \\
30 \text { elderly }\end{array}$ & $\begin{array}{l}\text { Sphygmomano } \\
\text { meter and } \\
\text { stethoscope }\end{array}$ & 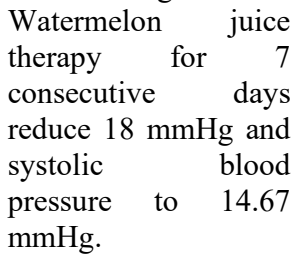 \\
\hline
\end{tabular}




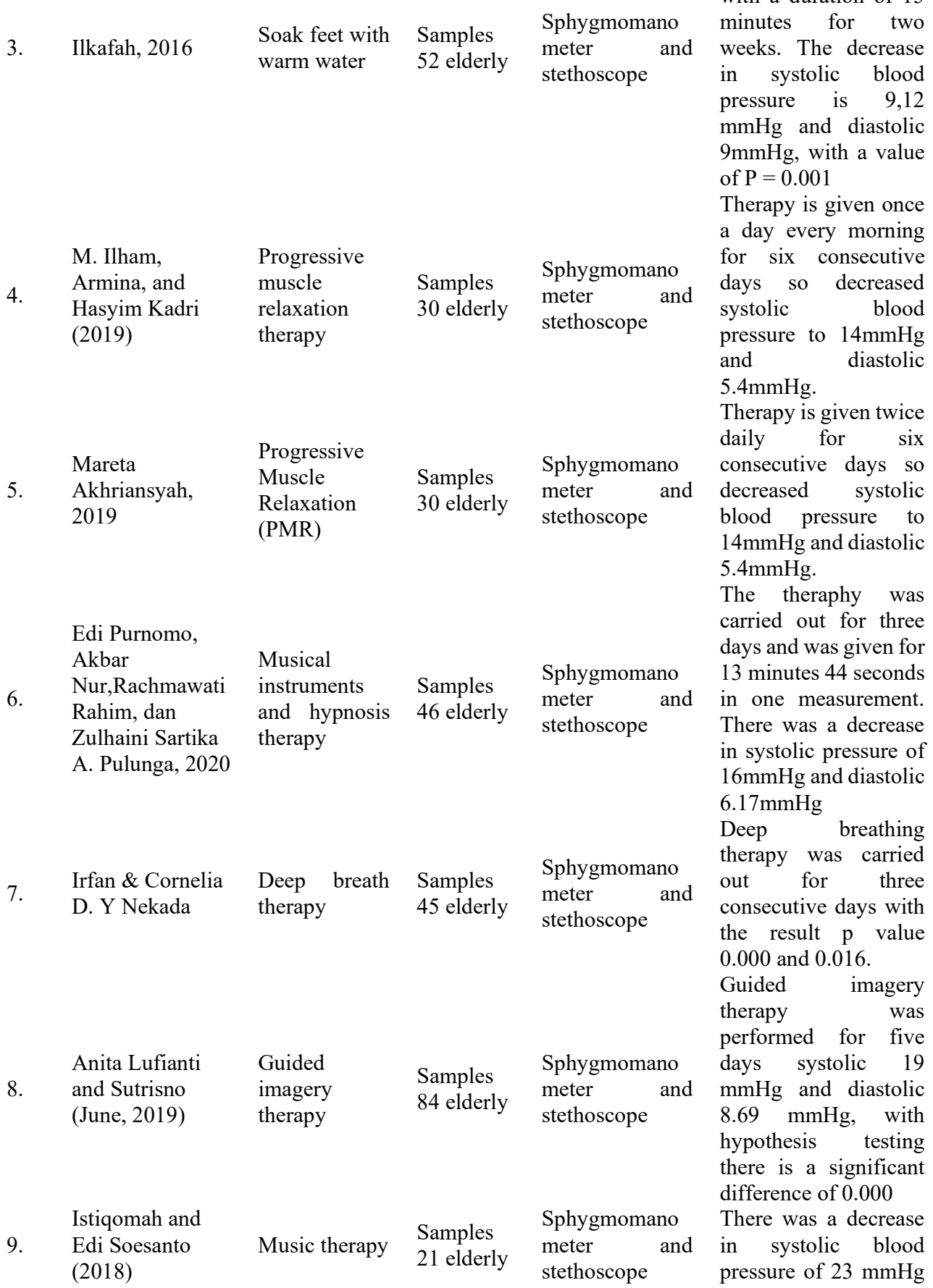

Warm water foot bath therapy $\left(39^{\circ} \mathrm{C}\right)$ were carried out twice a day with a duration of 15 minutes for two in systolic blood pressure is 9,12 $\mathrm{mmHg}$ and diastolic $9 \mathrm{mmHg}$, with a value Therapy is given once a day every morning days so decreased systolic blood pressure to $14 \mathrm{mmHg}$ and diastolic $5.4 \mathrm{mmHg}$

Therapy is given twice daily for six ive days so meter and decreased systolic blood pressure to $14 \mathrm{mmHg}$ and diastolic $5.4 \mathrm{mmHg}$ days and was given for

Edi Purnomo,

Nur,Rachmawati

Rahim, dan

46 elderly

Zulhaini Sartika

therapy

meter and in one measurement.

in systolic pressure of $16 \mathrm{mmHg}$ and diastolic $6.17 \mathrm{mmHg}$

Deep breathing

Sphygmomano meter and consecutive days with the result $\mathrm{p}$ value 0.000 and 0.016 .

Guided imagery performed for five days systolic 19 and Sutrisno imagery Samples meter and $\mathrm{mmHg}$ and diastolic (June, 2019) therapy 84 elderly (2018)

Samples stethoscope pressure of $23 \mathrm{mmHg}$ 


\begin{tabular}{|c|c|c|c|c|c|}
\hline 11. & $\begin{array}{l}\text { Kusumoningtyas } \\
\text {, Dwinta Nuke } \\
\text { and Ratnawati } \\
\text { Diah (2018) }\end{array}$ & $\begin{array}{l}\text { Slow stroke } \\
\text { back massage } \\
\text { therapy }\end{array}$ & $\begin{array}{l}\text { Samples } \\
30 \text { elderly }\end{array}$ & $\begin{array}{l}\text { Sphygmomano } \\
\text { meter and } \\
\text { stethoscope }\end{array}$ & $\begin{array}{l}\text { minutes } 2 \text { times per } \\
\text { week for } 3 \text { weeks. The } \\
\text { results obtained in the } \\
\text { intervention group } \\
\text { were } 12.66 \mathrm{mmHg} \text { and } \\
\text { diastolic } 9 \mathrm{mmHg}\end{array}$ \\
\hline 11. & $\begin{array}{l}\text { Ni Wayan } \\
\text { Trisnadewil } \\
\text { Theresia Anita } \\
\text { Pramesti, I made } \\
\text { Sudarman } \\
\text { Adiputra }\end{array}$ & $\begin{array}{l}\text { Slow stroke } \\
\text { back massage } \\
\text { therapy }\end{array}$ & $\begin{array}{l}\text { Samples } \\
30 \text { elderly }\end{array}$ & $\begin{array}{l}\text { Sphygmomano } \\
\text { meter and } \\
\text { stethoscope }\end{array}$ & $\begin{array}{l}\text { The results showed a } \\
\text { decrease in systolic } \\
\text { blood pressure of } \\
12.459 \mathrm{mmHg} \text { and } \\
\text { diastolic } 7.898 \mathrm{mmHg}\end{array}$ \\
\hline 12. & $\begin{array}{l}\text { Herdiman and } \\
\text { Rizall Ilbert }\end{array}$ & $\begin{array}{l}\text { Murotal } \\
\text { Theraphy }\end{array}$ & $\begin{array}{l}\text { Samples } \\
30 \text { elderly }\end{array}$ & $\begin{array}{l}\text { Sphygmomano } \\
\text { meter and } \\
\text { stethoscope }\end{array}$ & $\begin{array}{l}\text { Murottal therapy for } \\
15 \text { minutes for } 3 \text { days } \\
\text { with the results of a } \\
\text { reduction in systolic } \\
\text { blood pressure of } \\
10.07 \text { mmHg and } \\
\text { diastolic } 7.60\end{array}$ \\
\hline 13. & $\begin{array}{l}\text { Yogie Bagus } \\
\text { Pratama, Hanny } \\
\text { Rasni, and } \\
\text { Wantiyah (2018) }\end{array}$ & $\begin{array}{l}\text { Cupping } \\
\text { therapy }\end{array}$ & $\begin{array}{l}\text { Samples } \\
22 \text { elderly }\end{array}$ & $\begin{array}{l}\text { Sphygmomano } \\
\text { meter and } \\
\text { stethoscope }\end{array}$ & $\begin{array}{l}\text { Performed once with a } \\
\text { span of } 15-30 \text { minutes } \\
\text { with a p value of } 0.004 \\
\text { (systolic) and } 0.046 \\
\text { (diastolic) }\end{array}$ \\
\hline
\end{tabular}

and diastolic $10 \mathrm{mmHg}$ with a p-value of 0.001

Giving therapy 30 minutes 2 times per week for 3 weeks. The intervention were $12.66 \mathrm{mmHg}$ and $\mathrm{mmH}$

The results showed a decrease in systolic meter and blood pressure of stethoscope $\quad 12.459 \mathrm{mmHg}$ and diastolic $7.898 \mathrm{mmHg}$

Murottal therapy for minutes for 3 days Sphygmomano meter and reduction in systolic diastolic 7.60

Performed once with (diastolic)

\section{Discussion}

Based on the literature review that the authors found, non-pharmacological therapy plays an important role in increasing the effectiveness of hypertension therapy. Non-pharmacological therapy is therapy that does not cause side effects. Research conducted by 108 respondents, found $60 \%$ of them using a combination of pharmacological and non-pharmacological therapy. And $15-40 \%$ use pharmacological therapy. This concept was developed by world nursing figure Florence Nightingale.

Researchers divided the non-pharmacology therapy for Indonesian elderly into three groups. Firstly, suitable research is non-pharmacological therapy through elderly exercise, a series of physical activity movements that are simple, systematic and can be carried out by the elderly. Second, the relaxation therapy and the third is diet, restriction or good dietary regulation to maintain and overcome the increase in blood pressure. In this case, according to the research criteria of the researcher is watermelon juice therapy. Adequacy of potassium properly can maintain blood pressure and make positive changes in the blood pressure of people with hypertension.

\section{Conclusion}

This literature review shows the important role of nonpharmacological therapy which can be used as an adjunct therapy to reduce systolic and diastolic blood pressure in elderly with 
hypertension. It is proven by the results of the study that there are differences between the intervention group and the control group. Where the intervention group experienced a decrease in systolic and diastolic blood pressure faster, compared to the control group who was only given pharmacological therapy. In conclusion, the results of the review literature that have been conducted state that non-pharmacological therapy acts as a pharmacological adjunct therapy that can reduce systolic blood pressure ranging from $9 \mathrm{mmHg}$ to $23.33 \mathrm{MmHg}$ and decrease diastolic pressure ranging from 5,4 $\mathrm{mmHg}$ to $14.67 \mathrm{MmHg}$. Researchers suggest that future studies use literature with a higher level of evidence based and more journals.

\section{References}

[1] WHO. World Population Ageing 2019. United Nations: New York.2019

[2] Kemenkes, R. Analisis Lansia Indonesia. 2017; Retrieved from https://pusdatin.kemkes.go.id/article/view/18012600001/analisis-lansia-di-indonesia-2017.html

[3] Dewi, S. R.. Buku Ajar Keperawatan Gerontik (1st ed.). Yogyakarta: Deepublish. 2014

[4] Kemenkes. Hasil Utama Riskesdas.2018; Retrieved from http://www.kesmas.kemkes.go.id/assets/upload/dir_519d41d8cd98f00/files/Hasil-riskesdas2018_1274.pdf

[5] WHO. World Hypertension Day 2019. Retrieved from https://www.who.int/cardiovascular_diseases/world-hypertension-day-2019/en/; 2019

[6] Kemenkes. Hasil Utama Riskesda.2018;Retrieved http://www.kesma 1274.pdf

[7] Hidayat. Efektivitas Pemberian Tambahan Terapi Non Farmakologis Untuk Mencegah Kenaikan Tekanan Darah Pada Penderita Hipertensi Stadium I (Studi di Wilayah Kerja Puskesmas Baturetno I Kabupaten Wonogiri. Jurnal Ilmu Kesehatan Masyarakat; 2010

[8] Muhadi. Analisis JNC 8 : Evidence-based Guideline Penanganan Pasien Hipertensi Dewasa. JNC $8,43(1), 54-59 ; 2016$

[9] Sari, R. P., Restipa, L., \& Putri, M. Y. Pengaruh Pemberian Jus Semangka Terhadap Penurunan Tekanan Darah Pada Lansia Penderita Hipertensi Di Wilayah Kerja Puskesmas Lubuk Buaya Padang Tahun 2017. Jurnal Ilmu Kesehatan, 1(1), 79-86; 017;2017

[10] Nur, H. T. R. F.Pengaruh Senam Hipertensi Lansia Terhadap Penurunan Tekanan Darah Lansia Dengan Hipertensi Di Panti Wreda Darma Bhakti Kelurahan Pajang Surakarta. Jurnal Kesehatan, 10(1), 26-31. Retrieved from http://journals.ums.ac.id; 2

[11] Nurhayati, S. R. P. K. E. Pengaruh Senam Lansia Terhadap Tekanan Darah Pada Lansia Hipertensi Di Puskesmas Walantaka. Jurnal Ilmiah Kesehatan, 12(12), 41-48; 2017

[12] Berek, P. A. L. Effectiveness Of Slow Deep Breathing On Decreasing Blood Pressure In Primary Hypertension: A Randomized Controlled Trial Of Patients In Atambua, East Nusa Tenggara. : : International Journal of Science, 1(2), 1-14; 2015

[13] Akhriansyah, M. Pengaruh Progressive Muscle Relaxation (PMR) terhadap Penurunan Tekanan Darah pada Lansia Hipertensi di Panti Sosial Tresna Wherda Palembang Provinsi Sumatera Selatan Tahun 2018. Jurnal Ilmiah Universitas Batanghari Jambi, 19(1), 11-16. https://doi.org/10.33087/jiubj.v19i1.544; 2019

[14] Febita, I., \& Fitriana, V. Penerapan Hipnoterapi Terhadap Penurunan Tekanan Darah Pada Lansia Penderita Hipertensi. Jurnal Profesi Keperawatan, 6(2), 134-144; 2019

[15] Wijayanto, T., \& Sari Rita. Perbedaan Pengaruh Terapi Masase Dengan Minyak Aromaterapi dan Minyak VCO Tekanan Darah Pasien Hipertensi Primer. Jurnal Kesehatan, 8(2), 23-30; 2015

[16] Bagus, P. Y., Rasni Hanny, \& Wantiyah. Pengaruh Terapi Bekam Kering Terhadap Tekanan Darah Pada Lansia Dengan Hipertensi Di PSTW Jember. The Indonessia Journal Of Health Science, 94 $101 ; 2018$

[17] Herdiman, \& Ilbert, R. The Effect of Murottal and Music Therapy on Reducing Blood Pressure in 
Palimanan Cirebon. KnE Life Sciences, 10(02), 818-823. https://doi.org/10.18502/kls.v4i13.5341; 2019

[18] Niken Setyaningrum, S. Efektivitas Slow Deep Breathing Dengan Zikir Terhadap Penurunan Tekanan Darah Pada Penderita Hipertensi. 3(1), 35-41; 2019

[19] Nurhayati, S. R. P. K. E. Pengaruh Senam Lansia Terhadap Tekanan Darah Pada Lansia Hipertensi Di Puskesmas Walantaka. Jurnal Ilmiah Kesehatan, 12(12), 41-48; 2017

[20] Des, J. D. C., Crepaz Nicole, \& TREND Group. Improving The Reporting Quality Of Nonrandomized Evaluations Of Behavioral And Public Health Interventions: The TREND Statement. TREND Statement, 94(3), 361-366;2004.

[21] Hall JE. Guyton, \& Hall. Textbook of Medical Physiology. Saunders: Elsevier Health Sciences; 2015

[22] Ilkafah. Perbedaan Penurunan Tekanan Darah Lansia Dengan Obat Anti Hipertensi Dan Terapi Rendam Air Hangat Di Wilayah Kerja Puskesmas Antara Tamalanrea Makassar. Jurnal Ilmiah Farmasi, 5(2), 228-235; 2016

[23] Sherwood. Fisiologi Manusia dari Sel ke Sistem (8th ed.). Jakarta: EGC;2014

[24] Irfan, \& Nekada, C. Pengaruh Terapi Napas Dalam Terhadap Penurunan Tekanan Darah Pada Lansia Dengan Hipertensi Di Balai Pelayanan Sosial Tresna Werdha Unit Abiyoso. Keperawatan Respati Yogyakarta, 5(2), 354-359; 2018

[25] Jasmarizal, S.L \& Yunita, D. Pengaruh Terapi Musik Klasik (Mozart) Terhadap Penurunan Tekanan Darah Sistolik Pada Lansia Dengan Hipertensi Di Wilayah Kerja Puskesmas Air Dingin Kecamatan Koto Tangah Padang Tahun. 1-4; 2011

[26] Yulastari, P. R., Betriana, F., \& Kartika, I. R. Terapi Musik Untuk Pasien Hipertensi. Real in Nursing Journal (RNJ), 2(2), 56-65; 2019

[27] Ratnawati, K. D. N. D. Efektifitas Terapi Slow Stroke Back Massage Terhadap Tekanan Darah Pada Lansia di RW001 Kelurahan Jombang Kecamatan Ciputat Kota Tangerang Selatan. Jurnal Ilmiah Keperawatan Orrthopedi, 2(2); 2018

[28] Rian, S. B. Pengaruh Rendam Kaki Air Hangat Terhadap Penurunan Tekanan Darah Pada Lansia Di Desa Jati Blimbing Rt 3 Rw 1 Kecamatan Dander Kabupaten Bojonegoro. Jurnal Kesehatan Majapahit;20 